\title{
原著 IV
}

\section{ラット実験的大腸癌にわける形態的 ならびに酵素組織化学的研究}

\author{
日本医科大学第 1 外科 \\ （主任：代田明郎教授）（指導：浅野伍朗教授）
}

増 森 興 治

DMH によるラット大腸癌発生過程について組織学的ならびに $\gamma$-glutamyl transpeptidase (GGT), alkaline phosphatase (ALP) の活性局在を中心に醇素組織化学的検索を行なった. 実験開始後16週目で肉眼的に 平板状隆起を示寸腺腫が比現し，19週目には無茎性ポリープ状の腺癌，さらに28週目になると全例に腺腫，癌 腫の発生がみられた，癌腫は組織学的に腺管腺癌, 印環細胞癌, 粘液癌であった。これらの病变における GGT，ALP の活性局在をみると，GGT は腺腫, 澏腫の閒質, 主として表層部強い活性局在を認めるとと もに高分化腺癌の一部, 低分化腺癌, 印環細胞癌では浸潤する癌細胞にもその活性が認められた. ALP 注腺 腫, 癌腫の間質に活性局在を認め, 電影的に注毛細血管内皮細胞, 組織球, 好酸球, 活性型間葉系細胞の細胞

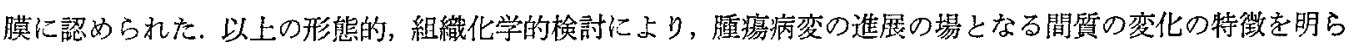
かにしたものと考えられる.

索引用語 : DMH，実験大腸癌， $\gamma$-glutamyl transpeptidase，alkaline phosphatase，閵葉系細胞，

\section{緒言}

近年，癌の発生や進展の過程での間質の果す役割が注 目されてきている1,2). 特に間質は上皮細胞の分化を制 御する重要な役割を担い, 発浢過程でも initiation, promotion に関与する重要な因子と考えられている ${ }^{32}$.

そこで著者は上皮と閒質の相互作用の見地から $1 ， 2-$ dimethylhydrazine (DMH) 投与ラット大腸䍄の発生 過程における粘膜上皮の変化と間質の血管效よび閒葉糸 細胞の動態を検索した，特に上皮細胞の䐺場化の指標と して r-glutamyl transpeptidase (GGT) ${ }^{4,5,6)}$ さらに血 管坊よび間質の細胞の指標として alkaline phosphatase (ALP) $)^{7}$ の活性局在を検討した.

その結果, ラット実験大腸癌発生過程において腫瘍発 生と問質の関連性を考える上で興味ある知見を得たので 報告する。

\section{材料および方法}

I. 材料: 体重120 150g, 雄性, ドンリュウラット 50 匹 (日本生物材料七ンター, 東京) を用い，MF 型固 型飼料（オリエンタル醉母株式会社，千葉）で飼育し た. 発癌剂の DMH（東京化生工業株式会社, 東京) は $7 \% \mathrm{NaHCO}_{3}$ および生理的食塩水（生食）で $\mathrm{pH} 7.0$ に調整し， $20 \mathrm{mg} / \mathrm{kg}$ 体重の割合で週 1 回，12週間皮下
注射した. 実験開始後 8 週目より 27 週目まで每週 2 匹 ずつ，28週目は10匹屠殺剖検し，大腸組織を実験に供 した. 対照として20週齢の DMH 無投与ラットを使用 した.

II. 方法

1. 光学顕微鏡的観察

大腸を盲腸, 盲腸に続き粘膜ヒダが herring-bone 状 を呈する部位を近位大腸，さらに肛門側の大腸を 2 等分 して口側より中位大腸および遠位大腸とし，それぞれの 部位において標本を作製した。標本採取後直ちに，一部 は O.C.T. COMPOUND (MILES 社, 米国) に包埋 後, ドライアイス，アセトンにて凍結させクライオスダ ットにて $4 \mu$ の連続切片を作成した。 また残りは冷アセ トン24時間固定後クロロホルムにより脱アセトンし，48 $\sim 50^{\circ} \mathrm{C}$ の軟パラフィンに包埋, $3 \mu$ の連続切片を作成 した. 谏結切片, 軟パラフィン切片をもに hematoxylin-eosin 染色を行い病理組織学的検索を行なった.

癌の分類は「大腸癌取り扱い規約」8〉に準じた。

\section{2. 電子顕微鏡的観察}

標本の一部を $2 \%$ glutaraldehyde を含む $0.1 \mathrm{M}$ cacodylate buffer pH 7.4kて固定細切後, $1 \%$ osmium tetroxide で固定後, エタノール系列で脱水, エポン樹 脂に包埋し，1 $1 \mu$ の厚さの切片を作製，1\% toluidine blue 染色を行ってオリエンテーション，その後超薄切 
片を作製，クエン酸鉛，酢酸ウラニル二重染色を施し， 日立 HU-12A 透過型電子顕微鏡にて観察した.

3. 酵素組織化学的観察

1) GGT 活性の局在の検討

凍結切片, 軟パラフィン切片を用いた. Rutenburg 法9) に従い, $\gamma$-L-glutamyl-4-methyl-2-naphthylamide (SIGMA 社, 米国) $2.5 \mathrm{mg}$ をそれぞれ0.05ml の DM$\mathrm{SO}, 1 \mathrm{~N} \mathrm{NaOH}$ で完全に溶解させ, 蒸留水 $1 \mathrm{ml}$, tris buffer $5 \mathrm{ml}$, 生食 $14 \mathrm{ml}$, glycyl glycine $10 \mathrm{mg}$, fast blue BB salt (SIGMA 社, 米国) $10 \mathrm{mg}$ を加え, $1 \mathrm{~N}$ $\mathrm{NaOH}$ を用いて $\mathrm{pH} 7.2-7.4$ に調整, この基質液に標本 を室温で15 20分間反応させた後, 生食で洗浄しメチル グリーンにて核染, グリセリン封入後観察した.

2) ALP 活性の局在の検討

凍結切片, 軟パラフィン切片を用いた. Burston 法10) に従い, 以下の基質液にて室温で 5 分間反応させケルン エヒトロート液にて核染し,グリセリン封入後観察し た.

\section{基質液}

naphthol AS-BI phosphate (SIGMA 社, 米国) $10 \mathrm{mg}$

fast blue RR salt (SIGMA 社, 米国) $20 \mathrm{mg}$

$0.05 \mathrm{M}$ 2-amino-2-methyl-1,3-propandiol buffer $\mathrm{pH} 9.8 \quad 10 \mathrm{ml}$

なお，標本の一部を Karnovsky の固定液にて 2 時間 固定, ビブラトームで $40 \mu$ に薄切し,

$0.1 \mathrm{M}$ cacodylate buffer $\mathrm{pH} 7.4$ で洗浄後

$0.2 \mathrm{M}$ tris-HCL buffer $\mathrm{pH} 8.54 .2 \mathrm{ml}$,

$0.1 \mathrm{M}$ sodium glycerophosphate $6.0 \mathrm{ml}$,

$15 \mathrm{mM}$ magnetide sulfate $7.8 \mathrm{ml}$,

$0.5 \%$ lead citrate $12 \mathrm{ml}$,

よりなる基質液に浸漬し, 室温にて20分間反応させ,

$1 \%$ osmium tetroxide, $0.1 \mathrm{M}$ cacodylate buffer $\mathrm{pH}$ 7.4 で 2 時間固定後脱水, Luft の方法に準じてエポン樹 脂包埋, 薄切し, 酢酸ウラン単染色を行い, 日立 $\mathrm{HU}-$ 12A 透過型電子顕微鏡にて観察した ${ }^{11}$.

\section{結果}

1. $\mathrm{DMH}$ 投与大腸粘膜の光学顕微鏡的所見

大腸全域に実験開始後 15 週目までは肉眼的に隆起性病 変はみられず, 組織学的に腺管構造の若干の乱れがみら れるのみであった. 16週目で粘膜には平板状の隆起性病 変が出現し, 組織学的には粘膜上皮細胞ならびに腺管に 異型性が認められた. しかしそれらの異型腺管の粘膜下 への浸潤，増殖は認められなかった．著者はこれを腺腫 として取り扱った.さらに19週目には無茥性ポリープ状
粘膜病変が出現し, 組織学的には異型腺管の粘膜下への 浸潤，増殖がみられ高分化腺癌の形態を示していた.こ れらの癌細胞は構造異型に乏しい明膫な腺管を形成して いた. 28 週目になると腺管構造が不明膫で管腔形成があ まり認められない低分化腺癌, 両者の中間に属すると思 われる中分化腺癌, さらに細胞内に豊富な粘膜を有し， 細胞が遊離した印環状細胞の増生, さらには豊富な粘液 産生を伴なう粘液癌など形態的には多彩な病像を示す癌 腫の発生がみられた．以上, DMH 投与により大腸に出 現した病変数は表 1 のごとく, 盲腸では腺腫 7 , 癌腫 6 , 近位大腸では腺腫 3 , 癌腫 19 , 中位大腸では腺腫 12 , 癌腫 23 , 遠位大腸では腺腫 9 , 癌腫 19 であった (Fig. 1, 2).

表 1 病変の発生部位と組織型

\begin{tabular}{l|rrrr|r}
\hline 組織型 $^{\text {部位 }}$ & 遠位大腸 & 中位大腸 & 近位大腸 & 盲腸 & 計 \\
\hline 腺 腫 & 9 & 12 & 3 & 7 & 31 \\
高分化腺癌 & 17 & 19 & 14 & 5 & 55 \\
中分化腺癌 & 2 & 3 & 2 & 0 & 7 \\
低分化腺癌 & 0 & 1 & 0 & 1 & 2 \\
印環細胞癌 & 0 & 0 & 1 & 0 & 1 \\
粘 液 癌 & 0 & 0 & 2 & 0 & 2 \\
\hline \multicolumn{1}{r|}{ 計 } & 28 & 35 & 22 & 13 & 98 \\
\hline
\end{tabular}

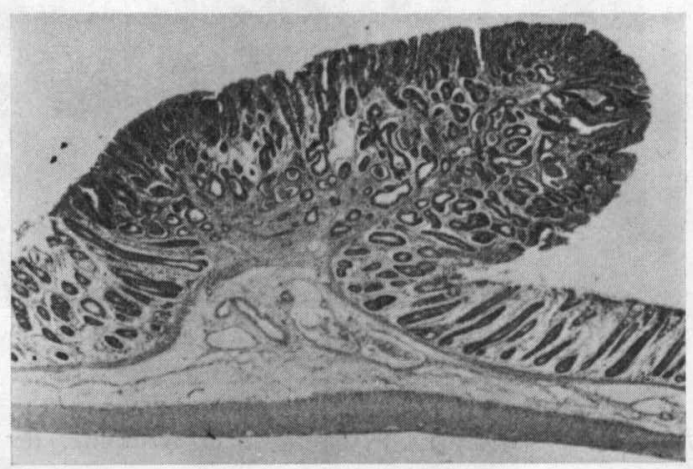

Fig. 1 実験開始後 28 週目に中位大腸にみられ た乳頭状腺腫. H-E 染色, $\times 20$

\section{DMH 投与大腸粘膜の電子顕微鏡的所見}

$\mathrm{DMH}$ 投与により16週以後より 粘膜上皮細胞の大小 不同性と粘液顆粒の減少, 表層上皮では微䋐毛の消失, 胞体内には多量のリボゾームの増生とミトコンドリアの 大小不同, さらに細胞接合が乱れ, 癌化にともない核・ 細胞質比は大きくなり核には大小不同性と核クロマチン の分布の不規則化がみられた (Fig. 3).

一方間質では毛細血管の増生と内皮細胞の腫大, 多形 性に富む間葉系細胞の増生, とくに myofibroblast の増 生と共に, 組織球, 好酸球など小円形細胞浸潤が観察され 


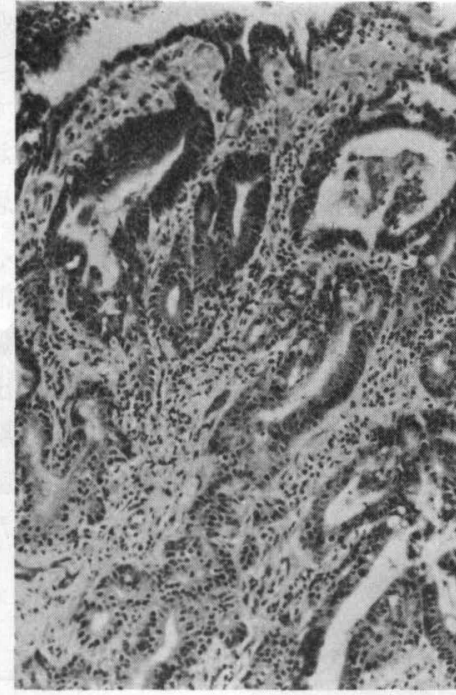

Fig. 2 実験開始後 28 週目に近位 大腸にみられた高分化腺 癌. H-E 染色, $\times 100$

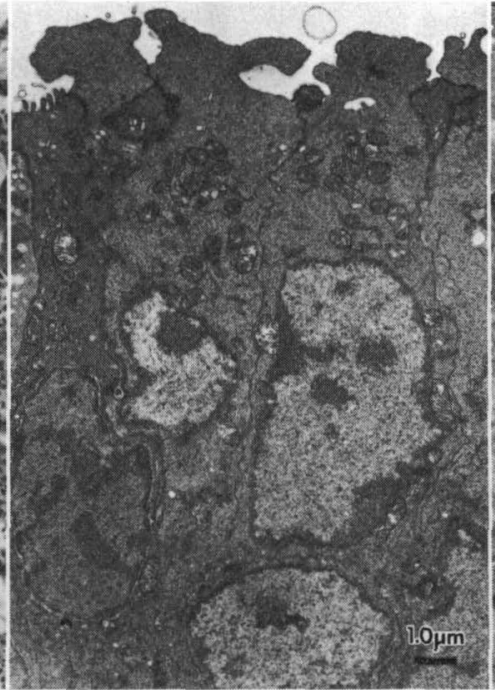

Fig. 3 粘膜上皮細胞に核の大小 不同，細胞間接合の乱れ， 微緁毛の消失がみられる. $\times 3600$

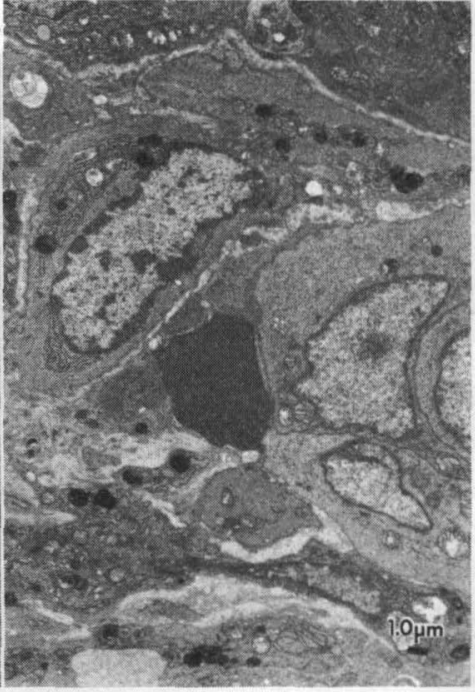

Fig. 4 腫瘍間質に多形性に富む間 葉系細胞がみられ，胞体内 には lysosome, dense body と微細線維の増生がみられ る. $\times 3600$

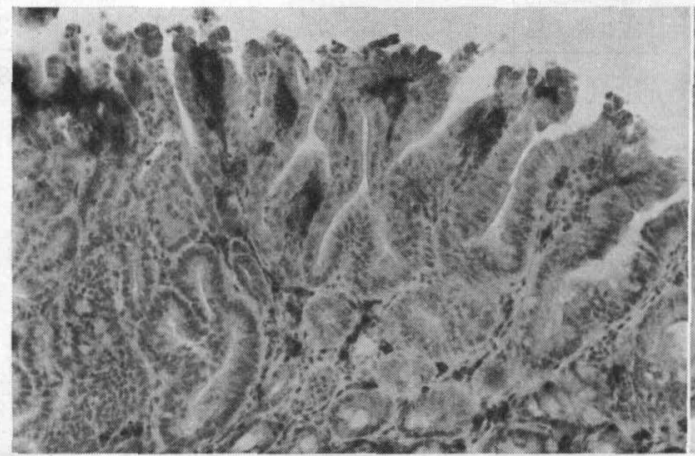

Fig. 5 腺腫の表層部の間質と小円形浸潤細胞に GGT の活性局在がみられる. × 100

た.これらの間葉糸細胞内の胞体内には lysosome, dense body の増生と粗面小胞体の発達がみられた（Fig. 4).

\section{3. 酵素組織化学的所見}

対照ラット大腸粘膜では GGT は上皮細胞および間 質にその活性は全く認められなかった. 大腸粘膜にみら れる各種病変での GGT の局在をみると, 腺腫では主と して腫瘍間質，とくに表層部の間質に高度の活性局在が 認められた (Fig. 5).なお腺腫に隣接する固有粘膜では 上皮細胞, 間質共に活性はほとんど認められなかった. 癌 腫では高分化腺癌ではその深達度にかかわらず，腺腫同 様に表層部の間質のみに活性局在が認められるものが多 かったが，一部に深層間質に活性局在が認められた (Fig. 6). しかし55病変のうち 5 病変に癌腫腺管内腔側

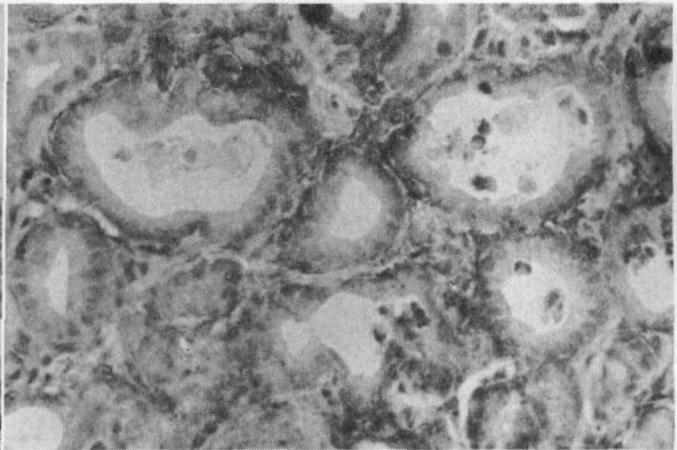

Fig. 6 高分化腺癌の一部にみられた腫瘍間質の GGT 活性局在を示す. $\times 200$

での GGT の活性局在が観察された(Fig. 7). とくにそ のうちの1 例では癌腫の浸潤先進部の管腔にのみ活性局 在が観察された．同様に中分化腺癌，低分化腺癌，印環 細胞癌, 粘液癌においても GGT の活性局在は癌腫表層 の間質にのみ陽性所見を認めたが，とくに印環細胞癌， 低分化腺癌では腫瘍細胞の一部に陽性所見が認められ， 癌細胞周囲の線維芽細胞などにもその局在が観察される ものがあった (Fig. 8). 以上, 組織所見と GGT 陽性 頻度の関係は表 2 のごとくであった.

一方ALPは対照ラット大腸粘膜では, そのほとんどが 粘膜固有層の毛細血管に局在していた．腺腫では全例に 増殖腺管周囲の間質に均一に強い活性が認められたが, 腫瘍細胞にはその活性は認められなかった (Fig. 9). そ して腺腫周囲の固有粘膜においては，その活性局在は小 


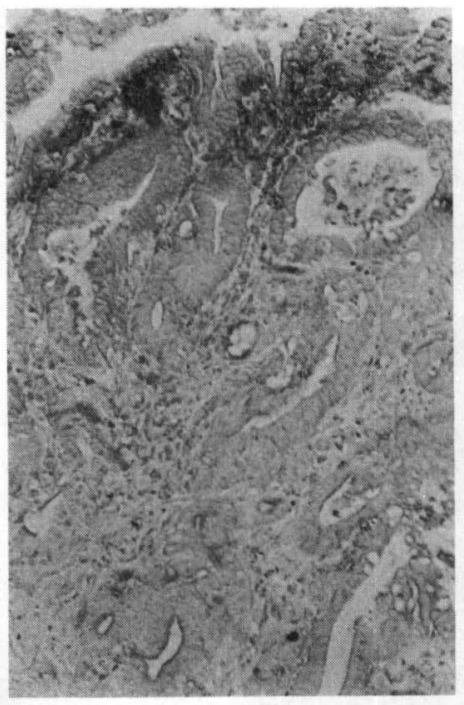

Fig. 7 高分化腺癌で，表層間質のみ ならず管腔内側にも GGT の 活性局在がみられる. $\times 100$

表 2 組織所見と GGT 陽性数, 頻度

\begin{tabular}{|c|c|c|c|}
\hline 組織所見 & 検索数 & 間質陽性数 (\%) & 腫瘍細胞陽性数 (\%) \\
\hline 腫 & 31 & $29(94)$ & $0(0)$ \\
\hline 高分化腺癌 & 55 & $53(96)$ & $5(9)$ \\
\hline 中分化腺癌 & 7 & $7(00)$ & $0(0)$ \\
\hline 低分化腺痹 & 2 & $2(100)$ & $2(100)$ \\
\hline 印環細胞癌 & 1 & $1(100)$ & $1(100)$ \\
\hline 粘 液 癌 & 2 & $2(100)$ & $0(0)$ \\
\hline 計 & 98 & $94(96)$ & $8(8)$ \\
\hline
\end{tabular}

血管にみられるのみであった．しかも癌腫ではいずれの 癌細胞にも活性は認められず, 全例組織型に関係なく, 間質に強い活性局在が観察された (Fig. 10). 微細構造 的には ALP は癌細胞の基底膜縁, 毛細血管内皮細胞, 浸潤増殖を示す組織球，好酸球ならびに多形性に富む間 葉系細胞の，とくに細胞膜にその活性局在が認められた

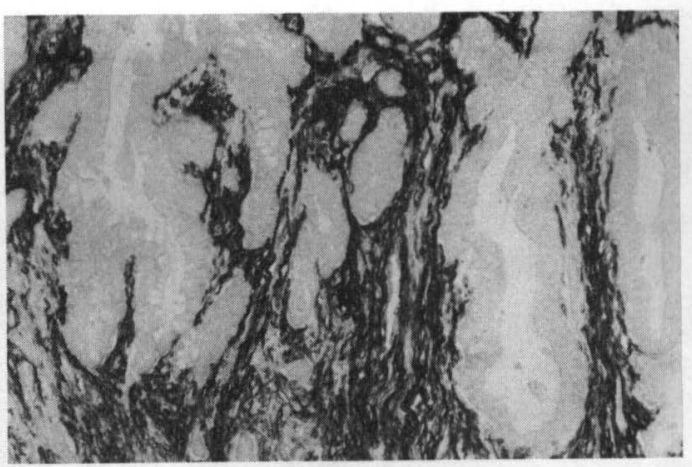

Fig. 10 癌腫では癌細胞には ALP の活性局 在はみられないが，間質にその局在 がみられる。 $\times 200$

(Fig. 11, 12).

\section{考按}

実験的に $\mathrm{DMH}$ 投与によりラット大腸粘膜に癌の発 生がみられることは既に報告12)されており，その発癌機 序については DMH の代謝産物が 経胆汁性および血行 性に粘膜上皮に作用するのではないかといわれてい る18)。ラット大腸癌の発生頻度, 部位, 形態に関しては 種差により多少の相違がみられ，近位側に多発するとい う報告 ${ }^{14)}$ と遠位側に多発するという報告 ${ }^{15)}$ がある．著者 の観察によるとその発生に関しては部位的には特徵はみ られず，形態的には腺管腺癌のみならず印環細胞癌さら には粘液癌の発生が観察された. 微細構造的には癌化に ともない上皮細胞の形態に多形性がみられ，分泌顆粒の 減少, 微絾毛の形成不全, リボゾームの増多, ミトコン ドリアの大小不同，核のクロマチンの不均一性など多彩 な形態像が観察された. 一方間質においても細胞の多形 性，とくに myofibroblast の増生と組織球，好酸球など 小円形細胞浸潤が観察され，この結果は癌増殖を考える 上で間質細胞の働きを注目する必要性を提示している。

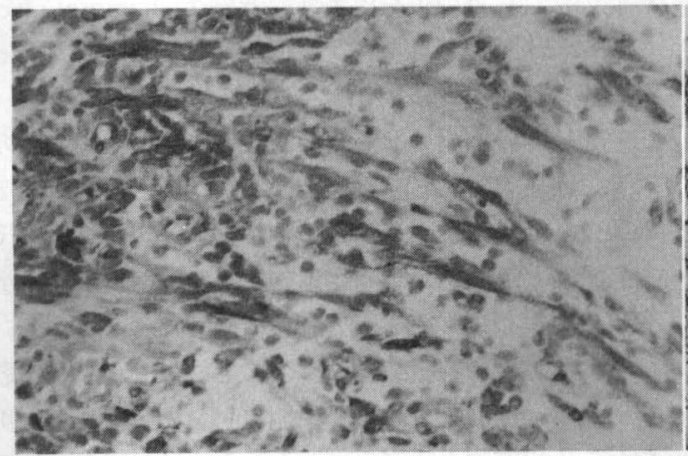

Fig. 8 癌腫間質にみられる間葉系細胞の GGT の活性局在を示す. $\times 200$

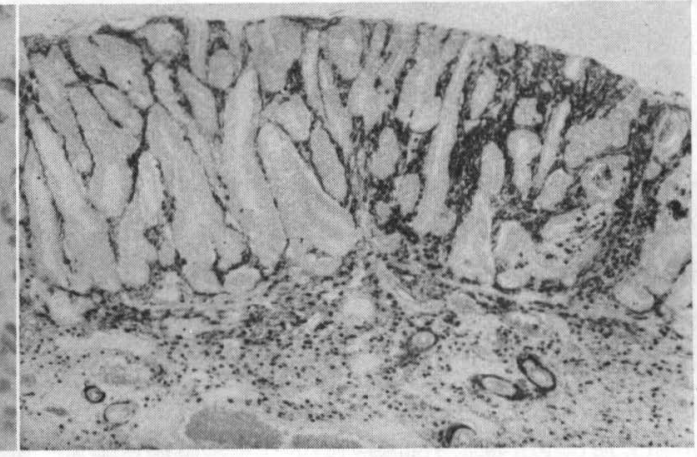

Fig. 9 腺腫の間質に均一性に ALP の活性局在 がみられる。 $\times 50$ 


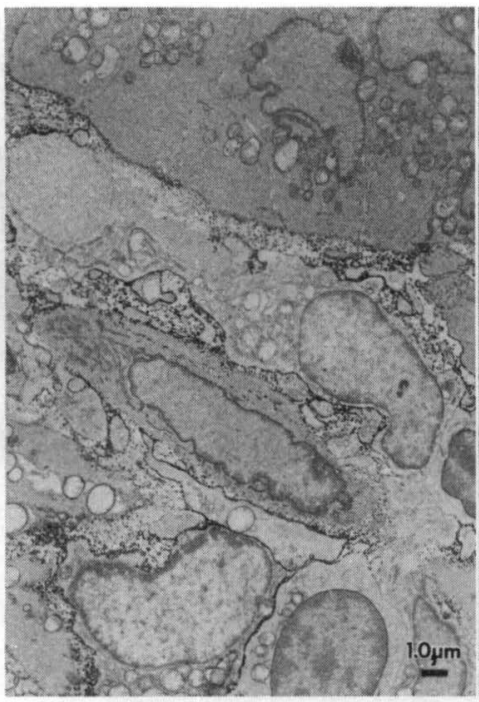

Fig. 11 癌腫において癌細胞の基底 膜縁ならびに間質の細胞の 細胞膜に ALP の活性局在 がみられる. $\times 1800$

GGT は酵素化学的に細胞膜に局在し, $\boldsymbol{\gamma}$-glutamyl 基 とアミノ酸や peptide の転移反応を触媒するすることに より, 細胞内の glutathione の分解と合成に関与してい るといわれている5 . また肝癌(2)など癌腫の発生時に増 加し, いわゆる oncofetal な性格を有する醳素であ り ${ }^{16)}$ ，近年，腫瘍マーカーとして注目されている. Fiala ら ${ }^{17) の ~} \mathrm{DMH}$ 誘発ラット大腸癌においても生化学的に GGT 活性の増加が報告されているが, 癌腫での局在に ついてはとくに明らかにされていない，奥らの報告 ${ }^{18)} に$ よると, ヒト大腸癌粘膜に明らかな GGT 活性の増加 が観察されている. 今回著者の観察において癌化した上 皮細胞での GGT の活性局在は限局的で, 高分化腺癌 の一部, 低分化腺癌, 印環細胞癌の浸潤部にその局在を 認めるものの, むしろその他の腺腫, 癌腫の間質, とく に表層部の間質に特異的な活性局在が認められることが 明らかになった。

藤田ら 23 は 胃の印環細胞癌において浸潤部の癌細胞は 固有層の癌細胞に比して基底膜形成が顕著であり, 部位 によって癌と間質の親和性が異なることを報告してお り, 癌間質の癌細胞増殖に果す役割が注目される. 著者 は $\mathrm{DMH}$ 投与ラット大腸粘膜に発生した腺腫, 癌腫の 表層部に強い酵素活性を認め, 深層浸潤部ではむしろそ の活性が低いという特異的な間質反応を観察した．また とくに腺管腺癌, 印環細胞癌の浸潤癌細胞にのみ GGT の活性局在を認めたことは興味深い.このように上皮と 間質の相互作用より癌腫の組織型および浸潤動態に差異 がみられる可能性が示唆された.

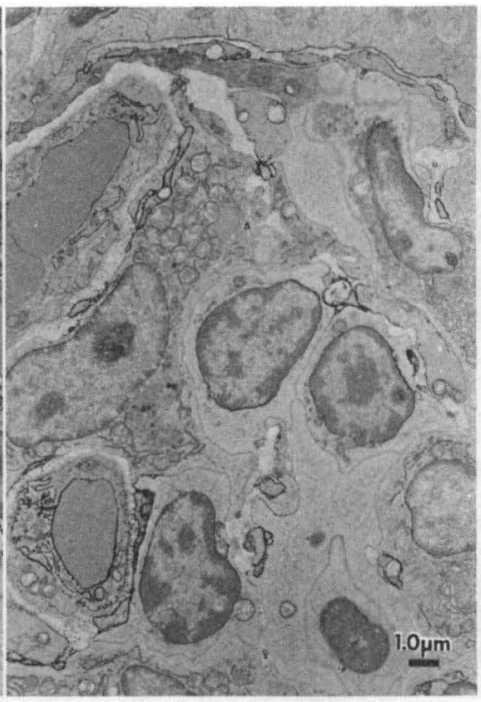

Fig. 12 癌腫において癌細胞の基底 膜縁ならびに毛細血管に ALP の活性局在がみられ る. $\times 1800$

ALP 活性の 局在については小腸上皮や化生胃粘膜上 皮の微䋐毛に一致して認められるが, 正常大腸粘膜上皮 ではその活性は認められず, 固有層の毛細血管に限局し ている，著者の観察では腺腫, 癌腫の発生にともないそ の間質に ALP 活性が著しく増加し，微細構造的にその 活性は毛細血管および間質に浸潤増生する組織球，好酸 球さらには myofibroblast など間葉糸細胞の細胞膜に限 局しているのが確認された. ALP の細胞膜での局在の 意義については未だ十分に解明されているとは言いがた いが，いわゆる細胞膜の機能立進をともなう線維芽細胞 あるいは血管増殖の指標としての意義が注目されてい る7).

Ohtani ら ${ }^{19)}$ は ヒト大腸の腺腫, 癌腫の間質に粗面小 胞体が発達し actin filament などを有する myofibroblast の増生を電顕的に観察している. そしてこの間質 細胞の活性化は腫瘍細胞よりの特異な humoral factor の分泌によるのではないかと推測している．著者の観察 で粘膜病変の間質に, 胞体内に小胞体などの小器官, actin などの 細線維の発達した活動型の間葉糸細胞がみら れた. さらにこれらの細胞では組織化学的にも GGT, ALP の活性局在が認められたことより盛んな蛋白代謝 を行っていると思われ，発癌剤投与大腸粘膜の特異な間 質反応を裏づけている. 著者の観察した $\mathrm{DMH}$ 投与 ット大腸粘膜の各種病変におけるこのような間質反応に ついては, 発癌剤 DMH の直接的な作用というよりは むしろ上皮細胞の腫演化にともなう特異な反応である可 能性がある. 
以上上り外来性の発癌物買は直接的に上皮細胞に働き その腫瘍化をむたらすが，その増殖，進展に際しての間 質の䣦きも無視できないという注目すべき結果を得た。

\section{結 論}

DMH によるラット大腸癌発生過程の組織学的およ び GGT, ALP の醳素組織化学的検菜から以下の結論 を得た。

1. 実験開始後 16 週目で肉眼的に平板状隆起を示す腺 腫が出現した. 19週目には無茎性ポリープ状の腺癌，さ らに28週目になると全例に腺腫, 癌腫の発生を認內, 組 織学的には腺管腺癌, 印環緗胞癌, 粘液澞であった。. 癌 腫間質には myofibroblast など間葉糸細胞の増生が観察 された。

2. 組織化学的に GGT は腺腫, 癌腫の間質, 主とし て表層部に強い活性局在を認めるとともに高分化腺癌の 一部，低分化腺癌，印環細胞癌では浸潤卞る癌細胞にも その活性が認められた。

3. ALP の活性局在は腺腫, 癌腫の間質, とくに毛 細血管内皮細胞，組織球，好酸球，活動型間葉禾細胞の 細胞膜に認められた。

4. 以上の形態的, 組織化学的検索に上り癌堌殖の進 展の場となる間質の变化の特徴を明らかにした.

稿を終るにあたり，御指導，御校閲を賜った日本医科 大学第 1 外科学教宝代田明郎教授，同第 2 病理学教室浅 野伍朗教授に深甚なる感詂の意を表します。

な执，本諭文の要旨は第42回日本癌学会総会招よで第 84回日本外科学総会に扔いて発表した。

\section{文献}

1）藤田晢也：胃癌発生に括ける“前癌性病変” の 意味一細胞動態の立埸より一。湢と化療 10 ： $459-470,1983$

2）藤田哲也，杉原洋行，伊藤良治ほか：細胞と間 質の相互作用加放み癌の発生之淮展の生物学。 癌と化潦 $11: 644-661 ， 1984$

3) van den Hooff $A$ : The part played by the stroma in carcinogenesis. Perspect Biol Med $27: 498-509,1984$

4) Fiala S, Fiala ES : Activation by chemical carcinogens of $\%$-glutamyl transpeptidase in rat and mouse liver. J Natl Cancer Inst 51 : $151-158,1973$

5) Vandelann M, Phares $W$ : $\gamma$-Glutamyltraspeptidase : a tumor cell marker with a phar- macological function. Histochem J $13: 865-$ 877,1981

6) Daoust $R$ : The histochemical demonstration of $r$-glutamyltranspeptidase activity in different populations of rat liver cell during azo dye carcinogenesis. J Histochem Cytochem $30: 312-316,1982$

7).Ten Cate AR, Syrbu S: A relationship between alkaline phosphatase activity and the phagocytosis and degradation of collagen by the fibroblast. J Anat $117: 351-359,1974$

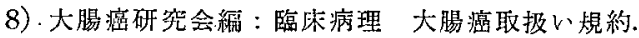
金原出版，1980

9) Rutenburg AM, Kim $\cdot H$, Fischbein JW, et al: Histochemical and ultrastractural demonstration of $\gamma$-glutamyl transpeptidase activity. J Histochem Cytochem $17: 517-526,1969$

10) Burston MS : Histochemical comparison of naphtol Asphosphates for the demonstration of phosphatases. J Natl Cancer Inst $20: 601$ 615,1958

11) Mayahara $H$, Hirano $H$, Saito $T$, et al : The new lead citrate method for the ultracytochemical demonstration of activity of nonspecific alkaline phosphatase (Orthophosphoric monoester phosphohydrolase). Histochemie $11: 88-96,1967$

12) Druckrey $H$, Preussmann $R$, Matzkies $F$, et al : Selektive Erzeugung von Darmkrebs bei Ratten durch 1, 2-Dimethylhydrazine. Naturwissenschaften 54: 285-286, 1967

13）成沢富雄：実験大腸癌の概況. 医のあ沖及 $103: 203-208,1977$

14) 上谷潤二郎, 武藤徹一郎：1,2-Dimethylhydrazine によるウイスター系ラット実験大腸癌 の検討。日消会誌 $75: 44-56,1978$

15）宦野陽介：DMH 㮇発ラット大腸踟の組織発 生に関する研究。日外会誌 $82: 1280-1290$, 1981

16）沢武紀雄，木谷 恒，米島 学活加: Novel $\gamma$ GTP isozyme. 癌と化療 $10: 1764-1773,1983$

17) Fiala $S$, Fiala $\mathrm{AE}$, Kellar $\mathrm{RW}$, et al : Gamma glutamyl transpeptidase in colon can. cer induced by 1, 2-Dimethylhydrazine. Arch Geschwulstforsch $47:$ 117-122, 1977

18）奥 雅志, 声田 脰: 七上大腸正常粘膜組織. 腺腫扰よび癌の組織化学的研究. 札幌医誌 $50: 277-293,1981$

19) Ohtani H, Sasano N : Stromal cells changes in hunan colorectal adenomas and carcinomas, an ultrastructural study of fibroblasts, myofibroblast and smooth muscle cells. Virchows Arch Pathol Anat $401: 209-222,1983$ 


\title{
Histological and Histochemical Studies on Colon Carcinoma in Rat Induced by 1,2-Dimethylhydrazine
}

\author{
K. Masumori \\ First Department of Surgery and Second Department of \\ Pathology, Nippon Medical School, Tokyo
}

The colon of rat administrated with 1, 2-Dimethylhydrazine was studied histologically and histochemically.

Sixteen weeks after administration of the carcinogen, adenomas were observed and after 19 weeks carcinomas, which showed tubular, signet-ring cell and mucinous carcinoma, were observed histologically.

The histochemical localization of $\gamma$-glutamyl transpeptidase (GGT) and alkaline phosphatase (ALP) was investigated in these tumors. GGT activity was negative in normal colon mucosa. In adenoma, GGT activity was found in stroma especially under the surface epithelium. It was also highly positive in the stroma of carcinoma and localized on the carcinoma cells in some cases. ALP activity was positive only on the capillaries in normal colon mucosa. On the other hand ALP activity was positive diffusely in the stroma of adenomas and carcinomas. Ultrastructurally, ALP activity: was noted on the plasma membrane of capillary endothelial cells, histiocytes, eosinophils and activated mesenchymal cells.

It was suggested that the histological and histochemical studies on the carcinogenesis of rat colon were useful for elucidating the interaction between tumor cells and mesenchymal cells. 